\title{
An economic assessment of local farm multi-purpose surface water retention systems in a Canadian Prairie setting
}

\author{
Pamela Berry $^{1} \cdot$ Fuad Yassin $^{1} \cdot$ Kenneth Belcher $^{2} \cdot$ Karl-Erich Lindenschmidt $^{1}$
}

Received: 4 January 2017 / Accepted: 12 July 2017/Published online: 27 July 2017

(C) The Author(s) 2017. This article is an open access publication

\begin{abstract}
There is a need to explore more sustainable approaches to water management on the Canadian Prairies. Retention pond installation schemes designed to capture surface water may be a viable option that would reduce water stress during drought periods by providing water for irrigation. The retention systems would serve to capture excess spring runoff and extreme rainfall events, reducing flood potential downstream. Additionally, retention ponds may be used for biomass production and nutrient retention. The purpose of this research was to investigate the economic viability of adopting local farm surface water retention systems as a strategic water management strategy. A retention pond was analyzed using a dynamic simulation model to predict its storage capacity, installation and upkeep cost, and economic advantage to farmers when used for irrigation. While irrigation application increased
\end{abstract}

Electronic supplementary material The online version of this article (doi:10.1007/s13201-017-0592-7) contains supplementary material, which is available to authorized users.

Pamela Berry

pamela.berry@usask.ca

Fuad Yassin

fuad.yassin@usask.ca

Kenneth Belcher

ken.belcher@usask.ca

Karl-Erich Lindenschmidt

karl-erich.lindenschmidt@usask.ca

1 Global Institute for Water Security, University of Saskatchewan, 11 Innovation Boulevard, Saskatoon, SK S7N 3H5, Canada

2 Department of Bioresource Policy, Business and Economics, University of Saskatchewan, Saskatoon, SK S7N 3H5, Canada crop revenue, the cost of irrigation and reservoir infrastructure and installation costs were too high for the farmer to experience a positive net revenue. Farmers who harvest cattails from retention systems for biomass and available carbon offset credits can gain $\$ 642.70 /$ hectare of harvestable cattail/year. Cattail harvest also removes phosphorus and nitrogen, providing a monetized impact of $\$ 7014 /$ hectare of harvestable cattail/year. The removal of phosphorus, nitrogen, carbon, and avoided flooding damages of the retention basin itself provide an additional $\$ 17,730-\$ 18,470 /$ hectare of retention system/year. The recommended use of retention systems is for avoided flood damages, nutrient retention, and biomass production. The revenue gained from these functions can support farmers wanting to invest in irrigation while providing economic and environmental benefits to the region.

Keywords Surface water retention systems - Irrigation · Water management - Nutrient retention - Biomass production - Economic assessment

\section{Introduction}

There is a need to explore more sustainable approaches to water management on the Prairies (Bower 2010; Pittman et al. 2011; Government of Manitoba 2014). The flow and storage of water on the Prairies is critical to maintaining the environment, economy, and livelihoods of its population (Belcher 1999; Hearne 2007; Pomeroy et al. 2005). Channelized drainage systems, such as ditches and culverts throughout the landscape, are used to deal with flood waters (La Salle Redboine Conservation District (LSRCD) 2007; Venema et al. 2010). This strategy works well when there is adequate access to water and land use 
practices do not create nutrient pollution issues (Bower 2007; Venema et al. 2010). However, recent years have seen a dramatic increase in nutrient pollution and subsequent diminishing water quality (Rao et al. 2012; Government of Manitoba 2014). Drainage systems increase nutrient amounts being removed from the landscape, subsequently impacting water quality (Venema et al. 2010). Drainage can also increase the negative effects of floods by amplifying flood peaks via increased streamflow and reduced infiltration rates, which then have greater force to cause damage (Venema et al. 2010). Subsequently, there is a need to explore more sustainable methods of water removal on the Prairies.

The creation of local farm water retention systems, designed to capture and store surface water, may be a viable adaptation strategy (Pavelic et al. 2012). Local farm water retention systems allow for the detainment of water captured during spring runoff as well as during precipitation events, either directly or due to transport by surface runoff. This provides water storage that can be drawn on when groundwater supplies become depleted (Vorogushyn et al. 2012; Pavelic et al. 2012). They also serve to reduce downstream peak flow and aid in retaining flood waters which reduces associated flood risks downstream (Agriculture and Agri-Food Canada 2012; Pavelic et al. 2012). If water is released from the reservoir, they serve to replenish groundwater stores downstream (Pavelic et al. 2012). Under drought conditions, these systems enable farmers to draw water from the reservoirs to support crop irrigation (Pavelic et al. 2012). These systems have been effective for increasing and stabilizing crop yields via irrigation in locations such as Texas, Kansas, Kentucky, India, and Thailand (Arnold and Stockle 1991).

However, adaptation does not come without barriers. Access to funds for irrigation infrastructure can be difficult to attain. A large irrigation installation can cost millions of dollars that is simply not feasible for some communities (Bonsal et al. 2011). It becomes important to consider the economic costs and benefits associated with different adaptation strategies as management decisions are often based on this information (Belcher 1999). While irrigation provides an economic gain during drought years, it also increases operational costs for water supplies (Samarawickrema and Kulshreshtha 2008). The size and holding capacity of retention systems also need to be considered to maximize benefits while limiting the initial costs of building a surface water retention system (Gohar et al. 2013). The size of the farm and amount of crop requiring irrigation will influence the size of retention pond best suited for the area. Few studies have been conducted on the economic feasibility of widespread adoption of retention systems for irrigation purposes on the Prairies. Due to Manitoba's limited irrigation development, there is also a lack of literature on the economic feasibility of irrigation development within the province.

Strategies need to provide drought proofing of crops as well as limiting damages caused by floods in non-drought years to reduce risk to farmers and the region. Strategies should also allow for sustainable water management by providing multiple benefits when possible, such as bioproduction and nutrient retention (Government of Manitoba 2014). According to the Lake Winnipeg Stewardship Board (2006), retention basins should be further reviewed to determine how effective and appropriate they can be as a nutrient abatement option in Manitoba. Surface water retention systems are ideal sites for nutrient retention as they act as concentration sites within a watershed for collecting excess nutrients allowing for maximum nutrient removal from bioproducts such as cattails. Surface water retention systems have shown success in reducing nutrient and sediment loading in various locations worldwide. Within America and Europe, retention systems have reduced total nitrogen by $38-56 \%$ and total phosphorus by $17-82 \%$, with reduction levels dependent on the size and type of retention system (Tiessen et al. 2011; Sharpley et al. 1996; Kovacic et al. 2006; Salvia-Castellvi et al. 2001; Avilés and Niell 2007; Uusi-Kämppä et al. 2000). On the Canadian Prairies, dams were found effective in reducing total suspended sediment (65-85\% reduction), particulate nitrogen (41-43\% reduction during snowmelt, $7-11 \%$ reduction from summer rainfall events), and particulate phosphorus (27-38\% reduction in snowmelt runoff) (Agriculture and Agri-Food Canada 2012). A system of dams within one watershed provided a reduction in peak flow of $9-19 \%$ from spring snowmelt runoff and 13-25\% from rainfall runoff (Agriculture and Agri-Food Canada 2012). Another on-farm retention pond in Saint-Samuel, Quebec was found to reduce peak flows by $38 \%$, on average, from rainfall runoff events (Chrétien et al. 2016). These additional benefits provided by retention ponds bolster the benefits of retention systems when they are not required for irrigation (Grosshans et al. 2012; Government of Manitoba 2014; Rittenburg et al. 2015).

Biomass production is another benefit of multi-purpose surface water retention systems. In Manitoba, cattails are being promoted for bioproduction and nutrient management as the plant grows most successfully on marginal crop land and in wet areas (Grosshans et al. 2014). Research by the International Institute for Sustainable Development (IISD) has found that cattails at Pelly's Lake, Manitoba, absorb up to $20 \mathrm{~kg} /$ hectare of phosphorus and remove $160 \mathrm{~kg} /$ hectare of captured nitrogen as they grow. They also provide 15-20 tonnes/hectare of biomass. The resulting biomass can be used for varying bioproducts such as solid fuel with a heat capacity of $17-20 \mathrm{MJ} / \mathrm{kg}$ (Grosshans et al. 2014). It is assumed that the high percentage of 
nitrogen being captured in cattails will not increase nitrogen emissions to the air. Modern biomass boiler systems, like the ones cattail and blended fuel pellets, are primarily burned in, are very efficient, have much more complete burning, and are controlled for reduced nitrous oxide emissions. Most of the nitrogen should be released as nitrogen gas and not as nitrous oxide. Any nitrogen emissions to the air will not cause any further environmental problems than traditional fuel sources. Bioproduct harvesting also addresses the finding from the Millennium Ecosystem Assessment. The assessment identifies overenrichment from nutrients as a critical concern to the environment globally (Venema et al. 2010). The removal of phosphorus from watersheds is essential to reducing nutrient loading to Lake Winnipeg, Manitoba (Bourne et al. 2002; Government of Manitoba 2014; Grosshans et al. 2014)

\section{Purpose and objectives}

The purpose of this research is to investigate the economic viability of adopting local farm surface water retention systems as a water management strategy, based on the output of a dynamic simulation model developed for the study area. The first objective of this study is to evaluate the capacity of retention ponds used for irrigation purposes to provide a net economic advantage for farmers not currently utilizing a retention pond for irrigation application. The second objective is to monetize the benefits of using retention basins for avoided flood damages, nutrient retention, and biomass production.

\section{Methods}

The interactions and complex feedback loops inherent in combining ecological and economic systems required a complex nonlinear system dynamics approach which embraced the links between these systems (Costanza et al. 1993; Belcher 1999; Low et al. 1999). A system dynamics model allows for hydrologic, reservoir, plant growth, irrigation, and economic modules to be created on a common spatial and temporal scale (Costanza et al. 1998). The method was chosen in part due to the software available for developing system dynamic models providing user-friendly interfaces which do not require extensive modeling knowledge. The software also provides an interface to communicate visually how the various components of the modeling system are interacting. This offers a better method of communicating the complexity of the modeling system to the end user than conventional code-based models.
A system dynamic model was chosen over existing crop models such as APSIM and DDSAT (Keating et al. 2003; APSIM Initiative 2016; DDSAT Foundation 2016) for several reasons. Several system dynamics models have been developed for water resources management (Mirchi et al. 2012; Qaiser et al. 2013). A system dynamics approach has been used successfully by several researchers on the Canadian Prairies (Belcher et al. 2003, 2004; Simonovic and Li 2004; Chen and Wei 2014; Hassanzadeh et al. 2014). The researchers involved had previous experience using the system dynamics approach (Belcher et al. 2004). A simplified model was commensurate with the dataset available. System dynamics also provides a method for model development that can be easily expanded for future research to include new modules or expansion of the developed modules from a local to regional scale. Finally, as the current research was focused on the multiple benefits of retention basins, the model needed to contain a strong component for modeling reservoirs.

\section{Study site}

Pelly's Lake site in south central Manitoba was chosen due to its preexisting water retention system offering multiple benefits. The system also has the capacity to be developed for irrigation due to its large water storage capacity and location. Landowners in the area, in combination with the La Salle Redboine Conservation District (LSRCD), agreed to create a back flood system offering multiple benefits. The current land use at Pelly's Lake was not meeting landowners' goals (La Salle Redboine Conservation District (LSRCD) 2013). Previous attempts to optimize hay production by draining the land using ditches and drains where Pelly's Lake is located had failed. Landowners were left with a wetland area filled with cattails due to the area being fed by an underground spring (La Salle Redboine Conservation District (LSRCD) 2013). The LSRCD is a nonprofit organization formed in 2002 covering an area of approximately $5200 \mathrm{~km}^{2}$ in southern Manitoba. Their mandate is to protect the natural resources of their district while promoting sustainable development (La Salle Redboine Conservation District (LSRCD) 2015a).

Pelly's Lake was engineered with a dike installation in 2014 to allow for floodwater retention, groundwater recharge, increased hay production, and nutrient removal in crop biomass (Grosshans et al. 2012). The reservoir, which has a storage capacity of $1,290,000 \mathrm{~m}^{3}$, allows for rain runoff and spring freshet to be captured each year (Armstrong et al. 2010; Pomeroy et al. 2011). The surface area of the lake is $1,210,000 \mathrm{~m}^{2}$, with the dike installation located at the northeast end (Fig. 1). Other potential study sites were smaller, single use, and not as representative installations. Pelly's Lake offered an opportunity to 
(a)

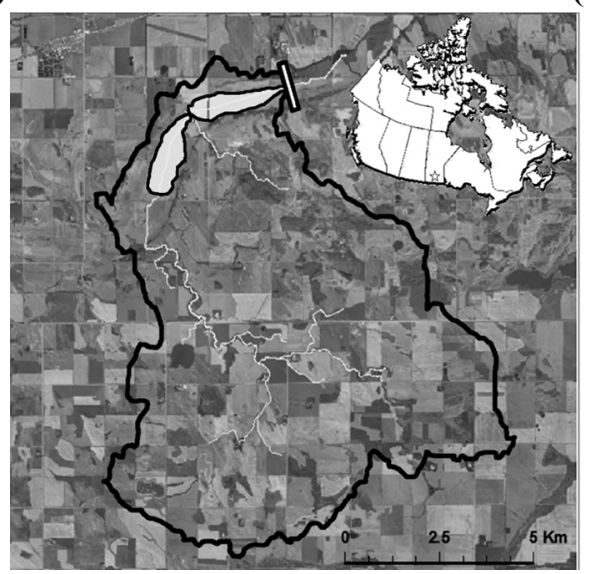

(b)

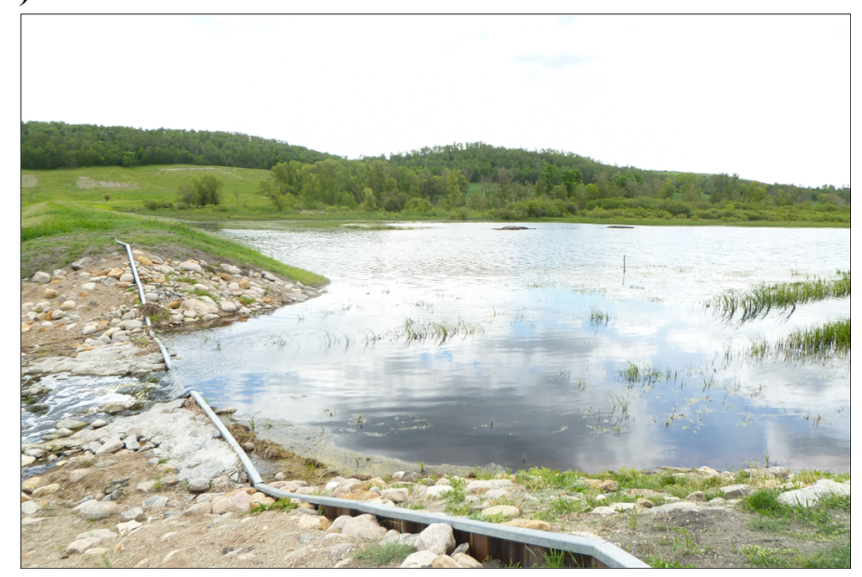

Fig. 1 Pelly's Lake, Manitoba a Pelly's Lake situated within the watershed boundary. Dike location is illustrated by the rectangle located at the northeast end of the lake b Concrete dike installation at Pelly's Lake on the left with a view of the lake to the west of the dike

determine the economic benefits of large, multifunctional retention systems on the Manitoba landscape. The site offered collaborations with the conservation district and researchers at IISD performing research at the site. Additionally, the location had the most available data for the study over other potential study sites.

The lake is situated within the Red River Basin, a predominantly flat land area with prime agricultural lands (Hearne 2007). The Pelly's Lake watershed is dominated by highly productive cropland consisting of well drained, loam to clay loam, mixed till soils in the rolling upland portion of the watershed (Stephenfield Lake Watershed Round Table 2005). The area has a semi-humid climate with average annual precipitation ranging from 480 to $560 \mathrm{~mm}$. A variety of annual crops are produced in the watershed, including spring wheat, canola, barley, and some forage production such as alfalfa. The total crop area within the Pelly's Lake watershed is $67 \mathrm{~km}^{2}$. Imperfectly drained soil conditions dominate the more level lacustrine soils below the rolling upland portion of the watershed (Stephenfield Lake Watershed Round Table 2005). Drainage as well as water retention potential in this area is poor which causes widespread flooding during times of excess water (Hearne 2007; La Salle Redboine Conservation District (LSRCD) 2007). Documentation in the area indicates that the soil types may not be ideal candidates for irrigation. However, this study is more interested in determining the economic feasibility of developing irrigation and if ample water can exist in local farm retention systems to support irrigation practice (Langman 1986, 1989).

\section{System-scale considerations}

The modeling system was developed based on a daily time step using a growing season simulation period running from April through September each year. The daily time step captured short-term components of the system while allowing for multiple years to be analyzed for a long-term analysis of the problem (Belcher 1999). The simulation period allowed for yearly spring freshet and precipitation events to be simulated. The time period 2002-2014 was modeled based on relevant climate condition data to capture precipitation variation and provide a longer-term evaluation of the potential for retention ponds to provide water for irrigation. Precipitation during the growing seasons of 2002-2014 ranged from 126 to $491 \mathrm{~mm}$, with an average rainfall of $338 \mathrm{~mm}$ (Government of Canada 2015). The analysis began in the year 2002 as 2002 and 2003 represented years that had above average crop insurance claims in Manitoba. Province wide, 2002 saw the third highest insurance claims for drought and dry seedbed between 1994 and 2014 at 19.6 million dollars, while 2003 saw the second highest claim at 25 million dollars (Manitoba Agricultural Services Corporation (2015)). The year 2004 was excluded from analysis due to incomplete hydrologic modeling data. Spatially, the study was confined to the watershed surrounding the study site as this is the area with the potential to directly benefit from the retention pond establishment. Decision rules were applied to mimic reality as closely as possible. These rules can lead to discreet behavior in the system such as discharge from the lake occurring when the lake level is above the crest.

\section{Modeling system}

The modeling software STELLA, a program designed specifically for modeling complex system dynamics, was adopted as the modeling platform for this study. The STELLA system dynamic model has also been used in a variety of biological and ecological sciences (Costanza et al. 2002; Belcher et al. 2004; Ouyang et al. 2010). The 
STELLA software allowed for the development of a dynamic modeling system using four main tools: (1) Stocks, a variable which accumulates and stores values. (2) Flows, which define inflow and outflow from a stock. (3) Converters, which hold information such as constants, unit conversions, functions, or time series. (4) Connectors, which act to connect features, variables, and elements to one another, indicating the relationship between components. Each stock, flow, and convertor allowed for the input of values and equations to specify the relationship among the model components (ISEE 2016).

The modeling system developed for this research was comprised of five modules: (1) hydrologic; (2) reservoir; (3) irrigation; (4) plant growth; and (5) economic (Fig. 3). The first module, hydrologic, allowed streamflow into the reservoir and initial reservoir volume from spring freshet to be added to the model. The reservoir module then calculated reservoir output based on preexisting dike parameters, evapotranspiration processes, runoff, and withdrawals taken for irrigation purposes. The irrigation module consisted of irrigation withdrawals and precipitation during the growing season informing water volume available for crops. The plant growth module modeled crop yields using water sufficiency curves and maximum crop yields specific to each crop. In the crop yield simulation, it was assumed that all other crop production inputs, including fertilizers and pesticides, were provided at optimal levels such that available water was the only constraint on crop production The economic module used crop yield outputs in combination with crop prices, crop production costs, and infrastructure costs to determine net revenue for each simulation year. For a detailed description of the parameters and equations used in the model, please see Online Resource 1. In addition to the sensitivity analyses detailed in this section, a more formal model evaluation was performed to ensure the newly developed modeling system was performing as expected. Sterman (2000) summarized the specific tests researchers use for improving system dynamic model performance and provided a detailed explanation of each test. Appropriate tests and questions focusing on the physical science components of model assessment as outlined in Sterman (2000) were addressed in Online Resource 2.

\section{Hydrologic model}

The Environment and Climate Change Canada environmental modeling system Modélisation Environmentale Communautaire-Surface and Hydrology (MESH) was used to model the hydrologic component of the target watershed. This distributed land surface model, commonly used in Canada for medium- to large-scale simulations, was run for the 2002-2014 study time period (Pietroniro et al.
2007; Verseghy 1991). Environment and Climate Change Canada uses MESH as part of an operational forecasting tool, and the system is currently being used within research projects such as the Drought Research Initiative (DRI) (University of Saskatchewan 2015). The modeling system, $\mathrm{MESH}$, is designed to simulate several hydrologic processes: evaporation, snow accumulation and ablation, interception, interflow, infiltration, recharge, baseflow, and overland and channel routing processes (Kouwen et al. 1993; Mengistu and Spence 2016). The model allows for streamflow to be simulated at any point within the watershed (Mengistu and Spence 2016). This ability is a major advantage of a fully distributed model (Viji et al. 2015).

MESH required multiple inputs to provide a complete distributed land surface model. The energy and water balance requirements for the model were determined utilizing the Canadian Land Surface Scheme (CLASS) 1 (Verseghy 1991) and CLASS 2 (Verseghy et al. 1993). The physically based land surface model, CLASS 1, calculated heat and moisture transfer at the surface, while CLASS 2 calculated energy and moisture fluxes at the canopy level (Verseghy 1991; Verseghy et al. 1993). The algorithms used in CLASS 1 and 2 were run on each grouped response unit (GRU) independently (Kouwen et al. 1993; Mengistu and Spence 2016). Precipitation data for MESH were from the Canadian precipitation analysis (CaPA) project which produces rainfall accumulations at a 6-h time step and resolution of $15 \mathrm{~km}$ over North America in real time (Mahfouf et al. 2007). Further required climatic data such as long-wave and short-wave radiation, humidity, pressure, and wind speed were from the Global Environmental Multiscale (GEM) Model (Côté et al. 1998; Pietroniro et al. 2007). Routing of water within the study area was performed within the MESH model using a storage-routing technique which applies the continuity equation as outlined in Kouwen et al. (1993):

$\frac{I_{1}+I_{2}}{2}-\frac{O_{1}+O_{2}}{2}=\frac{S_{2}-S_{1}}{\Delta t}$,

where $I_{1,2}$ represent inflow to the reach from overland flow, interflow, base flow, and channel flow $\left(\mathrm{m}^{3} / \mathrm{s}\right), O_{1,2}$ represent outflow from the reach $\left(\mathrm{m}^{3} / \mathrm{s}\right), S_{1,2}$ are storage in the reach $\left(\mathrm{m}^{3}\right)$, and $\Delta t$ is the time step of the routing in seconds. Subscript 1 represents the beginning time step quantities, and subscript 2 represents the ending time step quantities. The hydrologic model was validated using streamflow data for the study watershed and adjacent downstream watershed. The components precipitation, evaporation, runoff, and change in storage were examined within MESH to ensure inputs and outputs balanced the change in storage (Fig. 2). As we were only interested in streamflow into the retention basin, which would not be affected by the dike installation, it was not necessary to test 

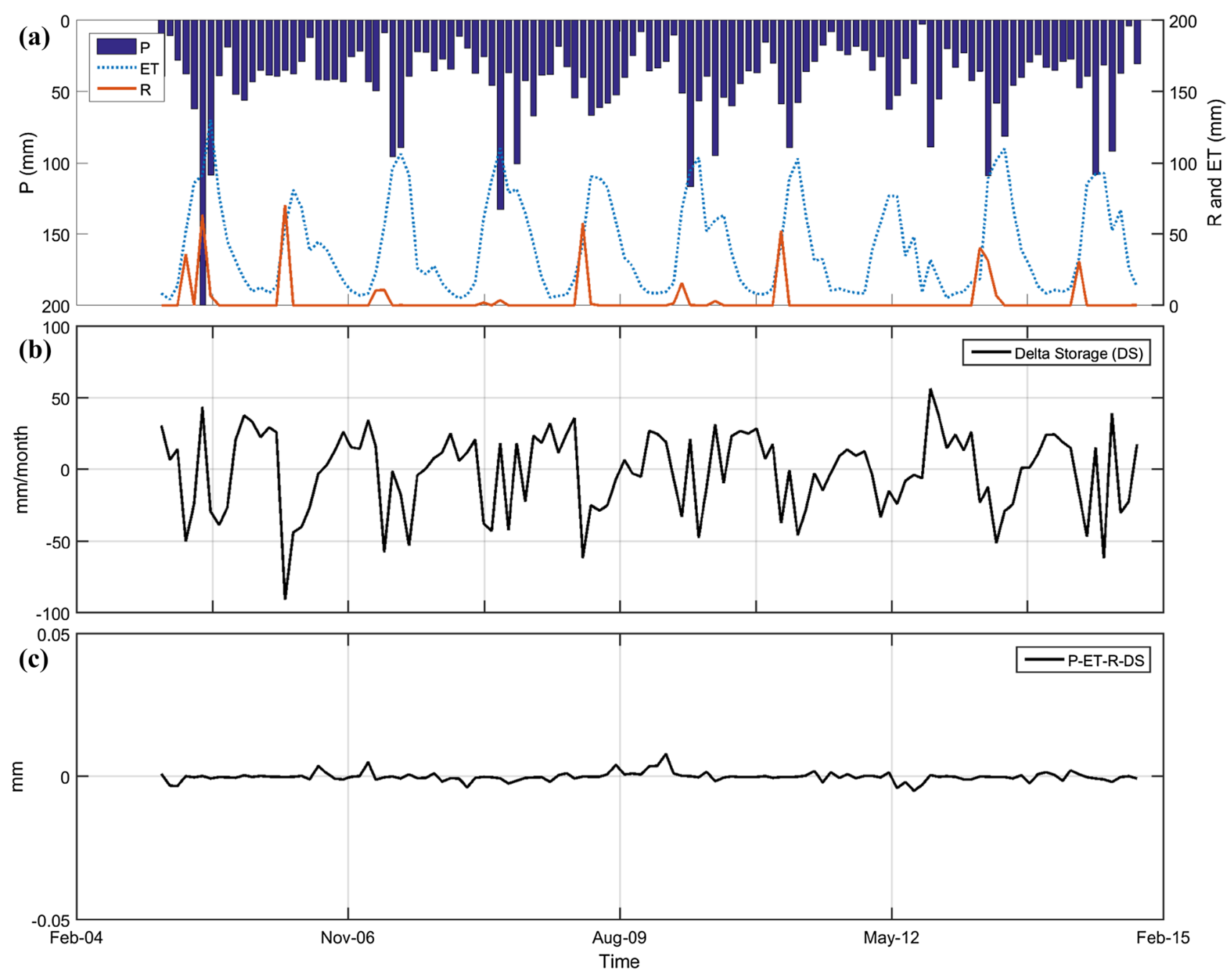

Fig. 2 Water balance for Pelly's Lake, Manitoba, showing precipitation (P), evapotranspiration (ET), runoff (R), and change in storage (DS). Validation of the hydrologic model for Pelly's Lake, Manitoba, with a precipitation $(\mathrm{P})$, evaporation $(\mathrm{ET})$, and runoff estimates over

the estimated flows for periods after the dike was installed. Daily discharge values and initial reservoir volume values from MESH were input into the model as represented in a stock-flow diagram of the modeling system within STELLA (Fig. 3).

\section{Irrigation module}

To model the effects of irrigation of crops on reservoir water levels, a variable allowing for abstraction amounts was included in the model. Water abstracted from the reservoir for crop irrigation, in combination with rain depth, provided the water available for crops (Belcher et al. 2004). For the purposes of this model, available water was applied to the four most common crops produced in the watershed. The total crop area within the watershed is $67 \mathrm{~km}^{2}$. The four most prevalent crops within the local time, $\mathbf{b}$ the study site's change in storage (DS) over time, and $\mathbf{c}$ the water balance illustrating the model's accurate accounting of all hydrologic components

Victoria and Lorne census areas as of 2011 are canola, spring wheat, alfalfa, and barley (Government of Canada 2011). Due to the low moisture deficits experienced in Manitoba, primarily dryland crops such as cereals and oilseed, which are also lower value crops, often do not provide enough financial benefit to merit irrigation (Gaia Consulting Limited 2007). As potato is the most commonly irrigated crop in Manitoba, but was not present in the study watershed, the model was also run replacing barley crops with potato crops for the 2006 year to determine the changes to economic benefits (Gaia Consulting Limited 2007; Government of Manitoba 2016). The model was adjusted to determine how much of the study cropland would need to be converted to potatoes in order to receive a positive net revenue from irrigation. The year 2006 was chosen for this simulation as it was the driest year within the study time period. The highest recorded, with recording 


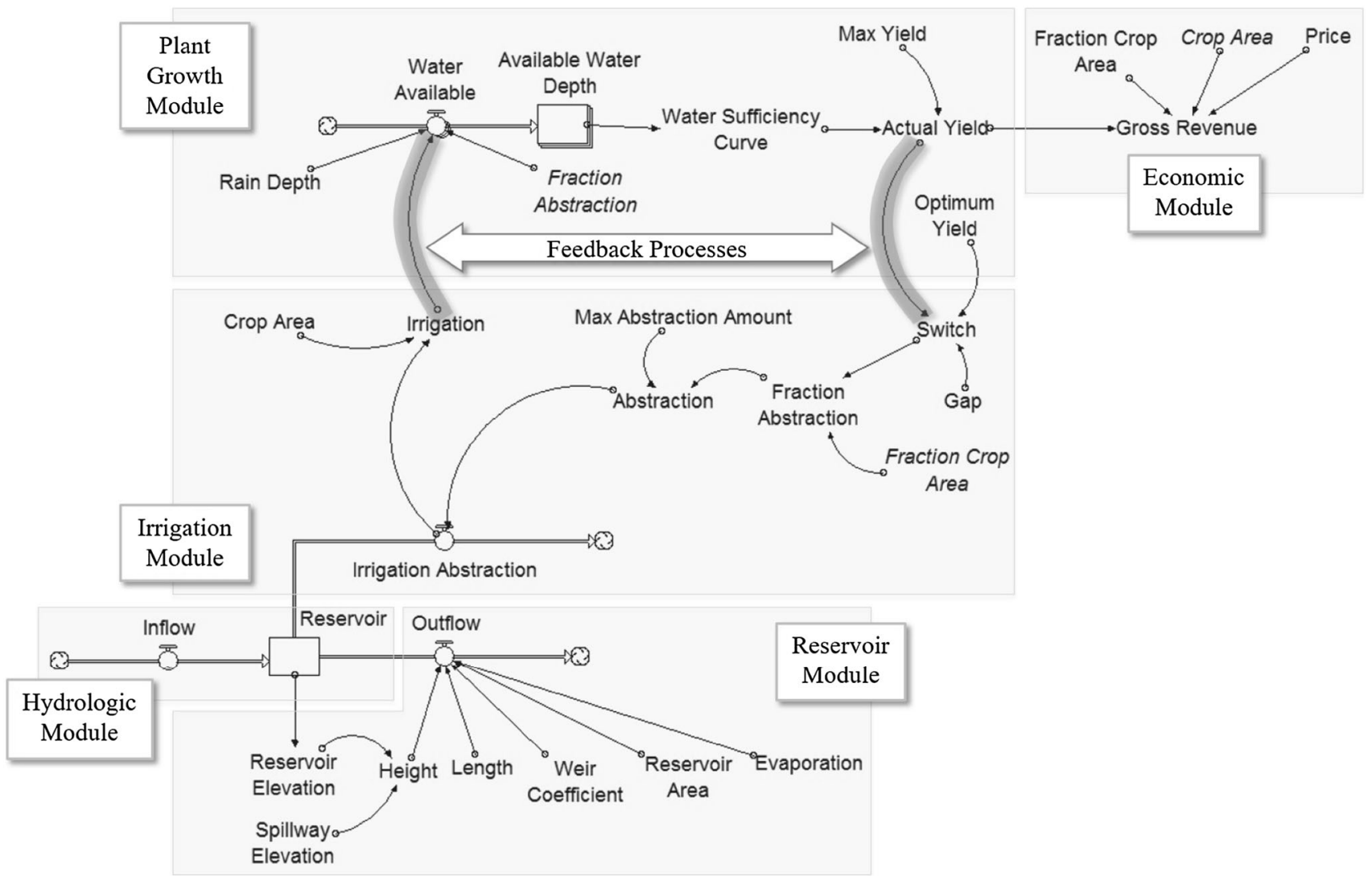

Fig. 3 Stock-flow diagram of five model system components: (1) hydrologic module with inputs from MESH, (2) reservoir module, (3) irrigation module, (4) plant growth module, and (5) economic

beginning in 1991, application of irrigation to potato also occurred in 2006 (Gaia Consulting Limited 2007). With potato crops replacing barley, the percentage of crop allocated to potato was set to $5,20,30,50$, and $100 \%$. Simulations were run with no irrigation, irrigation distributed across all four crops, as well as irrigation isolated to only the potato crops.

Irrigation was applied if the available water for a crop was only sufficient to provide $80 \%$ of that crop's optimum yield at a point in time during the growing season. This required the inclusion of a feedback loop within the model between actual yield and the switch used to initiate the withdrawal of irrigation. The withdrawn irrigation water subsequently created a feedback to water available for crops, impacting actual yield. As water available to plants was increased, actual yield was optimized to improve net revenue. A value of $80 \%$ was chosen as water stress causing yield reduction happens when water available for plants falls below $60 \%$ of optimum (Grinder 2000). To ensure water available for plants did not reach that level, irrigation would begin once a threshold for available water enabling $80 \%$ yield was met. This ensured water was only module. Feedback processes within the modeling system are noted and highlighted in gray

applied to a crop when sufficient water for optimal growth was not being met without irrigation.

\section{Plant growth module}

Each crop has a unique optimal water requirement that is represented in the model as crop-specific sufficiency curves. These curves determined yield based on water availability, which was calculated as the sum of precipitation and irrigation water (Belcher et al. 2004). On average within the study area, there is some initial spring soil moisture associated with snowmelt; however, for the purposes of this model, soil moisture was recharged with precipitation and/or irrigation water. All other factors affecting growth, such as nitrogen and phosphorus levels, and pesticides, were assumed to be applied at the optimal level such that water was the only limiting factor to crop yield. Irrigation amounts were optimized to provide the highest crop yield. The resultant crop yields were used in combination with crop prices, crop production costs, and input costs to determine the net economic revenue under irrigation. 


\section{Economic model}

Landscape-scale gross revenue was exported from the simulation model and input into Microsoft EXCEL to calculate landscape-scale net revenue. Production costs for the crop area were based on the average (per hectare) production costs for each of the four crops used in the study which were then weighted to reflect the proportion of each crop in the study area. Seed and treatment, fertilizer, fungicide, herbicide, and insecticide application along with fuel, machinery operation, lease, land taxes, interest costs, and average insurance costs were included in production costs. Production costs were adjusted for the 2006 simulation, when potato crops replaced barley, and the percentage of crop allocated to potato was varied. Production costs were subtracted from gross revenue (Government of Manitoba 2015a).

Input costs, including reservoir and irrigation installation and upkeep costs, as well as operating costs associated with each crop type, were constant for all simulations. A $5.125 \%$ interest rate was applied to the total reservoir and irrigation infrastructure costs for a 20 year time horizon, the typical serviceable life of reservoir infrastructure, to estimate the total cost of installation with accrued interest (Waelti and Spuhler 2012). The interest rate of $5.125 \%$ represented the current lending rate available to farmers through Manitoba Agriculture Services Corporation (MASC) for 20-year terms (MASC 2016). The cost of irrigation was assumed to capture any additional farm expenses that would be required during regular use such as increases in labor and equipment maintenance. A centerpivot sprinkler system was used for the irrigation estimate as they are the most commonly used irrigation systems in Manitoba (Gaia Consulting Limited 2007). It was assumed that farmers were responsible for the costs of reservoir establishment and irrigation infrastructure installation. Thus, net revenue for irrigated crops was calculated by the following equation:

Net Revenue Irrigation \& ReservoirInfrastructure

$=$ Gross Crop Revenue - Production Costs

- Operating \& Annualized Costs Irrigation \& ReservoirInfrastructure.

For simulations that did not include the reservoir and associated infrastructure, net revenue equaled:

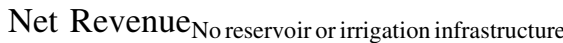

$=$ Gross Crop Revenue - Production Costs.

The secondary benefits of retention system installation were divided into two calculation categories: actual realized values and ecosystem goods and services. Actual realized values were calculated for biomass production via cattail harvest and subsequent carbon offset credits. Both values represent revenue a farmer could receive in the current market for cattail harvest. The ecosystem goods and services, free benefits an ecosystem provides to humans, were estimated for the additional benefits of cattail harvest and the retention basin itself. These benefits included nitrogen and phosphorus capture and removal, an average global social cost of carbon credit production, and avoided downstream flood damages. Nutrient removal was calculated separately for the retention basin and cattail harvest. This was due to the retention basin itself capturing nitrogen and phosphorus in the soil and lower two-thirds of unharvested cattail, and the cattail harvest removing captured nitrogen and phosphorus from the upper onethird portion of the cattail plant. A list of parameters, values, and sources used in the economic analysis are provided in Table 1 .

\section{Sensitivity analyses}

Several sensitivity analyses were performed to determine the impact of infrastructure price, crop price, initial reservoir volume, maximum daily irrigation water volume, and the gap between actual and optimal yield, on net revenue. A sensitivity analysis was performed on reservoir and irrigation costs under four scenarios: 10\% decrease, 5\% decrease, $5 \%$ increase, and $10 \%$ increase in infrastructure costs. Crop prices were increased and decreased 10, 25, and $50 \%$ on both irrigated and non-irrigated crops. A sensitivity analysis was performed to determine whether the initial water volume available in the reservoir impacted gross revenue. The six scenarios analyzed were: (1) $10 \%$ increase, (2) $10 \%$ decrease, (3) $25 \%$ increase, (4) $25 \%$ decrease, (5) $50 \%$ increase, and (6) $50 \%$ decrease in reservoir volume.

The next sensitivity analysis varied the maximum daily irrigation water volume available for withdrawal. Seven scenarios were performed with maximum daily water volumes adjusted in increments of $10,000 \mathrm{~m}^{3}$ from the maximum daily water volume of $15,000 \mathrm{~m}^{3}$ : (1) $5000 \mathrm{~m}^{3}$ (2) $25,000 \mathrm{~m}^{3}$, (3) $35,000 \mathrm{~m}^{3}$, (4) $45,000 \mathrm{~m}^{3}$, (5) $55,000 \mathrm{~m}^{3}$, (6) $65,000 \mathrm{~m}^{3}$, and (7) $75,000 \mathrm{~m}^{3}$. The last sensitivity analysis was performed on the gap between actual and optimum yield, a value used to determine whether irrigation application is required. Irrigation was triggered when available water dropped below the level that provided $80 \%$ of optimal yield. The gap was varied in increments of $10 \%$, with four scenarios: 60, 70, 90, and $100 \%$, triggering irrigation when available water dropped below the level that provided that percentage of optimal yield. 
Table 1 Parameter values and sources for the economic model

\begin{tabular}{|c|c|c|}
\hline Parameter & Value & Source \\
\hline Average production costs & $\$ 534.93 / \mathrm{ha}$ & Government of Manitoba (2015a) \\
\hline $\begin{array}{l}\text { Average insurance costs (included in average production } \\
\text { costs) }\end{array}$ & $\$ 42.57 /$ ha & Government of Manitoba (2015a) \\
\hline $\begin{array}{l}\text { Potato crop simulation average production costs as crop area } \\
\text { allocated to potato increases }\end{array}$ & $\begin{array}{l}\$ 815.33 / \mathrm{ha} ; \$ 1654.16 / \mathrm{ha} ; \\
\$ 2212.19 / \mathrm{ha} ; \$ 3322.88 / \mathrm{ha} ; \\
\$ 6070.58 / \mathrm{ha}\end{array}$ & Government of Manitoba (2015a) \\
\hline $\begin{array}{l}\text { Potato crop simulation average insurance costs (included in } \\
\text { average production costs) }\end{array}$ & $\begin{array}{l}\$ 53.76 / \text { ha }(5 \%) \\
\$ 261.86 / \text { ha }(100 \%)\end{array}$ & Government of Manitoba (2015a) \\
\hline Cost of retention system installation at Pelly's Lake, MB & $\$ 551,288.00$ & $\begin{array}{l}\text { La Salle Redboine Conservation District } \\
\text { (LSRCD) (2015b) }\end{array}$ \\
\hline Interest rate (applied over a 20-year time horizon) & $5.125 \%$ & $\begin{array}{l}\text { Manitoba Agricultural Services } \\
\text { Corporation (2016) }\end{array}$ \\
\hline $\begin{array}{l}\text { Annual value of retention system (includes } 2 \% \text { of installation } \\
\text { cost for expected yearly maintenance) }\end{array}$ & $\begin{array}{l}\$ 55,818 / \text { year } \\
\text { (\$8.33/ha of irrigated cropland/ } \\
\text { year) }\end{array}$ & $\begin{array}{l}\text { La Salle Redboine Conservation District } \\
\text { (LSRCD) (2015b) }\end{array}$ \\
\hline Annual value of center-pivot sprinkler irrigation installation & $\begin{array}{l}\$ 1,017,208 / \text { year } \\
\text { (\$141.88/ha of irrigated cropland/ } \\
\text { year) }\end{array}$ & $\begin{array}{l}\text { Grinder (2000), Gaia Consulting Limited } \\
\text { (2007) }\end{array}$ \\
\hline \multicolumn{3}{|l|}{ Secondary benefits } \\
\hline Net value of dry cattail biomass & $\$ 16.59 /$ tonne & $\begin{array}{l}\text { Dion and McCandless (2013), Grosshans } \\
\text { (2013) }\end{array}$ \\
\hline $\begin{array}{l}\text { Tonnes of carbon dioxide equivalent in one tonne of dry } \\
\text { cattail biomass }\end{array}$ & 1.05 tonnes & $\begin{array}{l}\text { Grosshans et al. (2012), Dion and } \\
\text { McCandless (2013) }\end{array}$ \\
\hline Dry cattail biomass production & 15 tonnes/ha & Dion and McCandless (2013) \\
\hline Total harvestable cattail area (the surface area of the lake) & 121 ha & ArcGIS \\
\hline $\begin{array}{l}\text { Social costs of carbon dioxide equivalent emissions (average } \\
\text { of source values) }\end{array}$ & $\$ 63.50 /$ tonne & $\begin{array}{l}\text { Clarkson and Deyes (2002), IPCC (2007), } \\
\text { Wilson (2008) }\end{array}$ \\
\hline $\begin{array}{l}\text { Carbon credit provided by a voluntary offset market in } \\
\text { Manitoba, Canada }\end{array}$ & $\$ 25.00 /$ tonne & $\begin{array}{l}\text { Manitoba Liquor and Lotteries Corporation } \\
\text { (2016) }\end{array}$ \\
\hline Carbon sequestration of retention basins & $\begin{array}{l}3.25 \text { tonnes of } \mathrm{CO}_{2} \text { equivalent/ha } \\
\text { of retention basin/year }\end{array}$ & Badiou et al. (2011) \\
\hline Cost of phosphorus removal (average of source values) & $\$ 60.00 / \mathrm{kg}$ & $\begin{array}{l}\text { Olewiler (2004), Wilson (2008), Sohngen } \\
\text { et al. (2015) }\end{array}$ \\
\hline $\begin{array}{l}\text { Nitrogen removal (estimated cost of removal from } \\
\text { constructed wetlands) }\end{array}$ & $\$ 36.34 / \mathrm{kg}$ & Collins and Gillies (2014) \\
\hline Phosphorus removed from wetlands (conservative estimate) & $80 \mathrm{~kg} / \mathrm{ha}$ of wetland/year & Olewiler (2004) \\
\hline $\begin{array}{l}\text { Phosphorus removed from cattail harvest (conservative } \\
\text { estimate) }\end{array}$ & $20 \mathrm{~kg} / \mathrm{ha}$ & Grosshans et al. (2014) \\
\hline Nitrogen removed from wetlands (conservative estimate) & $350 \mathrm{~kg} / \mathrm{ha}$ of wetland/year & Olewiler (2004), Wilson (2008) \\
\hline Nitrogen removed from cattail harvest & $160 \mathrm{~kg} / \mathrm{ha}$ & Grosshan et al. (2014) \\
\hline $\begin{array}{l}\text { Value of wetland flood control, based on avoided damage } \\
\text { costs }\end{array}$ & $\begin{array}{l}\text { \$741.30/ha of retention system/ } \\
\text { year }\end{array}$ & $\begin{array}{l}\text { Schuyt and Brander (2004), Brander } \\
\text { Brouwer and Wagtendonk (2013) }\end{array}$ \\
\hline $\begin{array}{l}\text { Avoided flood damages in watershed adjacent to study } \\
\text { watershed }\end{array}$ & $\$ 0.38 /$ ha of watershed/year & $\begin{array}{l}\text { Stanley Soil Management Association } \\
\text { (2000) }\end{array}$ \\
\hline
\end{tabular}




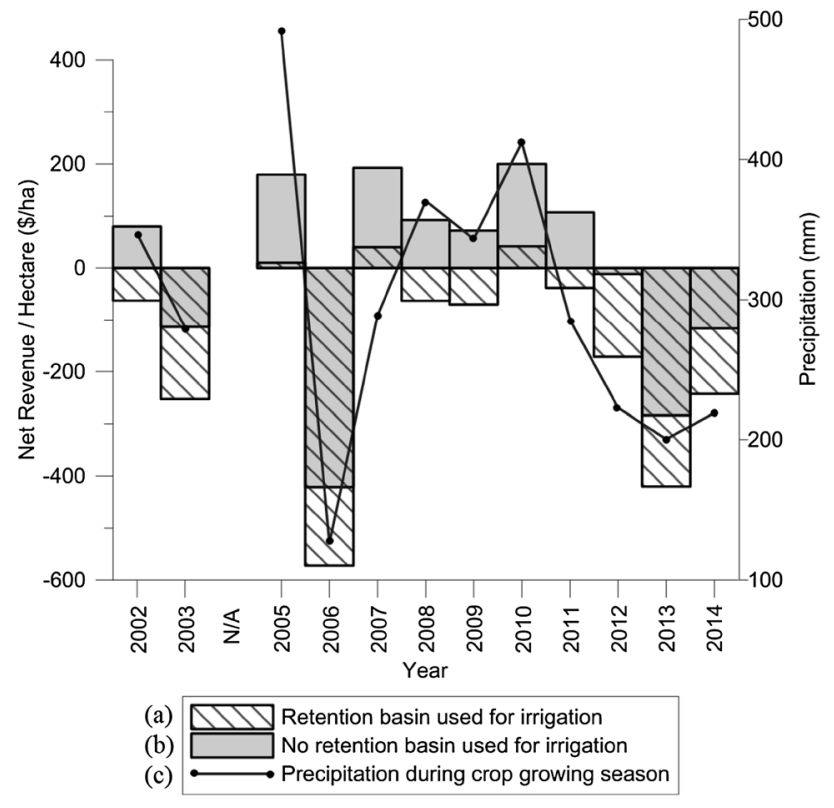

Fig. 4 Results for the 2002-2014 simulation period. a Yearly net crop revenue when irrigation is applied using water from the Pelly's Lake retention system. Irrigation and reservoir costs are accounted for. b Yearly net crop revenue without irrigation. Irrigation and reservoir costs are not included in net revenue. c Annual precipitation experienced for each simulation growing season, illustrating a large range in annual water availability

\section{Results}

\section{Multi-purpose surface water retention system used for irrigation application}

Annual net revenues were estimated for the 2002-2014 time period under two simulation scenarios: (a) crops were grown utilizing water abstractions from the Pelly's Lake retention system for irrigation and net revenue accounted for the associated infrastructure costs, and (b) crops were grown without the use of retained water from Pelly's Lake for irrigation and subsequently net revenue did not account for reservoir and irrigation infrastructure costs (Fig. 4). Annual growing season precipitation amounts varied each year's gross crop income (Fig. 4). Crops under irrigation experienced a decrease in net revenue due to the high cost of infrastructure costs, $\$ 160.00 /$ hectare. Subsequently, when the two simulations were compared to determine the change in net revenue when irrigation was applied using water from the retention system, net revenue decreased (Table 2). Irrigation did increase gross crop revenue (Table 2), but it was not enough of an increase to cover the costs of the irrigation and reservoir infrastructure.

Available precipitation strongly influenced the benefits of irrigation for the study period. Years with sufficient annual precipitation $(>400 \mathrm{~mm}$ ) experienced little benefit from irrigation as crop water requirements were being met

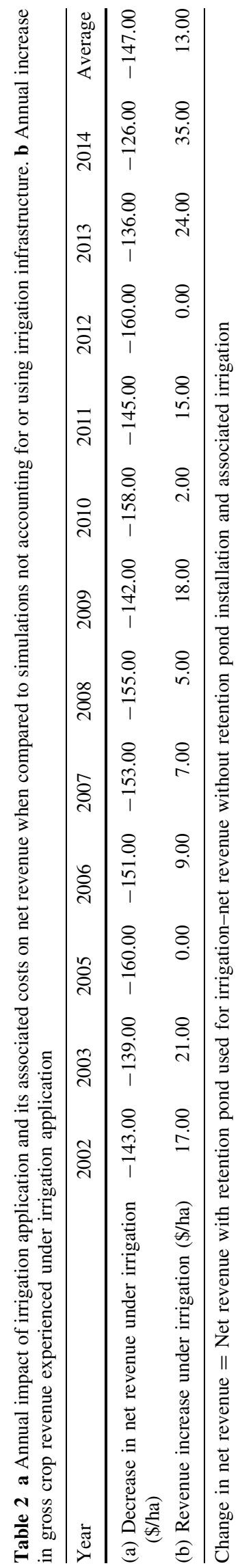




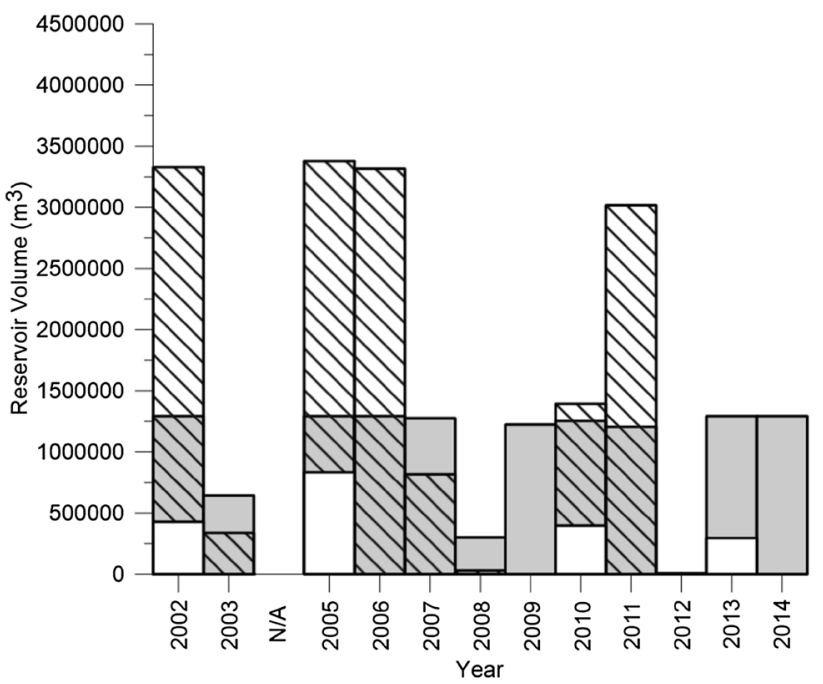

\begin{tabular}{|l|}
\hline 110 Initial reservoir volume \\
September total reservoir volume without irrigation abstractions \\
September reservoir volume after irrigation \\
\hline
\end{tabular}

Fig. 5 Initial reservoir volume at the Pelly's Lake retention system on April 15 of each simulation year, total reservoir volume at the end of the growing season (September 15), and September 15 reservoir volume under the irrigation scenario which utilized water abstractions from the reservoir

or exceeded. Crop yields increased with irrigation were insufficient to meet crop water requirements and thus irrigation increased gross crop revenue. The result was a gain in net crop revenue ranging from $\$ 5.00 /$ hectare in 2008 to $\$ 34.00 /$ hectare in 2014 . Reservoir volumes varied annually based on the volume of spring runoff and precipitation experienced throughout the growing season (Fig. 5). This fluctuation in water volumes impacted the availability of water withdrawals under the irrigation scenario simulations. One year, 2012, experienced a low initial reservoir volume and the lowest total reservoir volume for the growing season of $6000 \mathrm{~m}^{3}\left(1,030,000 \mathrm{~m}^{3}\right.$ average volume, $433,000 \mathrm{~m}^{3}$ standard deviation). Thus, in this year, irrigation was not applied to the crops because of the low reservoir volumes.

The year 2006 was used to simulate the economic benefits of partially or completely converting crop land to the high-value potato crop, the most commonly irrigated crop in Manitoba. Irrigation was applied across all crops or isolated to potato crops. Gross revenue increased under both scenarios, no irrigation and irrigation application, as the percentage of crop land allocated to potato increased (Fig. 6). Isolating irrigation just to potato instead of distributing it across all four crops had no observable impact. The potato crops water requirement was being sufficiently met when irrigation water was distributed across all four crops during the 2006 simulation year. The high production costs associated with potato crops ( $\$ 5807 /$ hectare) resulted

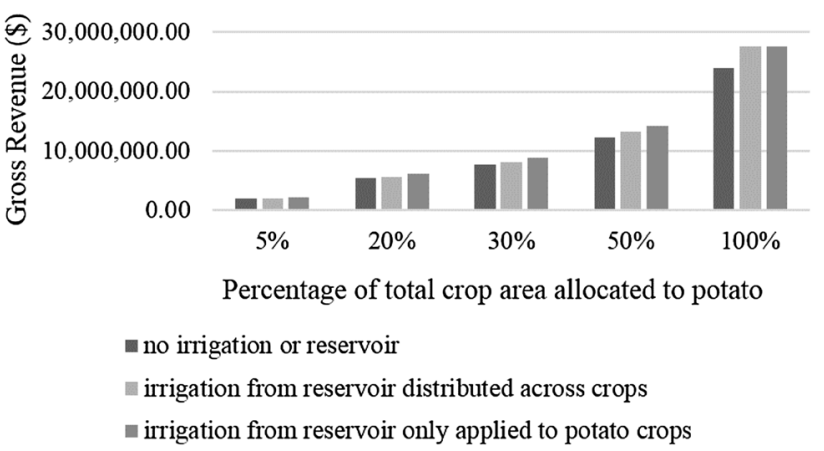

Fig. 6 Study area gross crop revenue for 2006, simulating various irrigation application scenarios, using four crops (alfalfa, canola, wheat, and potato), and adjusting the percentage of crop area allocated to potato to determine its impact on gross crop revenue

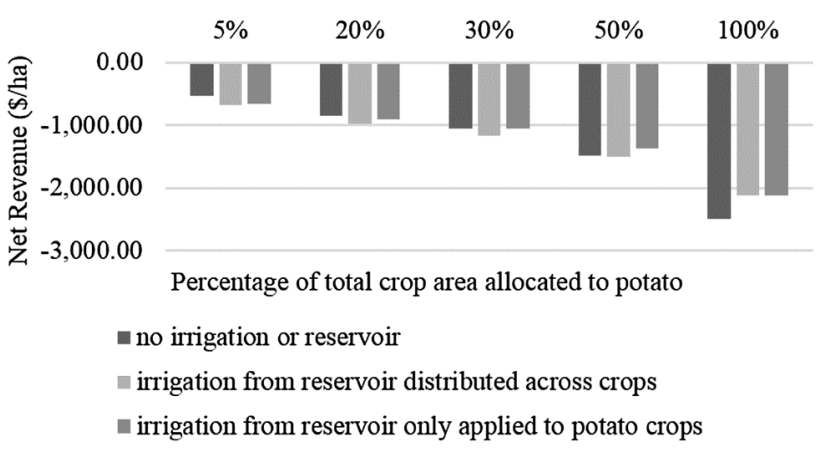

Fig. 7 Study area net revenue for 2006, simulating various irrigation application scenarios, using four crops (alfalfa, canola, wheat, and potato), and adjusting the percentage of crop area allocated to potato to determine its impact on net crop revenue. Costs associated with irrigation and reservoir infrastructure were accounted for when irrigation was applied

in net revenue decreasing as the percentage of crop allocated to potato increased (Fig. 7).

The average impact of irrigation water over the simulation period was an increase in annual crop revenue of $\$ 13.00 /$ hectare. However, due to the cost of irrigation and reservoir installation, this on average created a net cost of $\$ 147.00 /$ hectare each year in order to cover the infrastructure and operation costs. Converting cropland to the high-value potato crop did not provide a positive net revenue when irrigation was applied. Irrigation and reservoir installation at Pelly's Lake was too costly to enable positive net crop revenue throughout the simulation period, even when low-value crops are converted to high-value potato crops.

\section{Monetized secondary benefits of multi-purpose surface water retention systems}

The retention basin at Pelly's Lake, MB, provides economic and environmental benefits when biomass 
Table 3 Monetized additional ecosystem goods and services benefits of the retention basin at Pelly's Lake, MB

\begin{tabular}{lc}
\hline Variable & Value \\
\hline Actual realized values of harvesting cattails for biomass at Pelly's Lake, MB (\$/hectare of harvestable cattail) & 248.90 \\
Dry cattail biomass & 393.80 \\
Carbon credits for carbon offset creation & 642.70 \\
Total & 1000.00 \\
Monetized ecosystem goods and services benefits of harvesting cattails for biomass at Pelly's Lake, MB (\$/hectare of retention basin) \\
Carbon credits & 1200.00 \\
Phosphorus removed & 5814.00 \\
Nitrogen removed & 8014.00 \\
Total & 206.30 \\
Monetized additional ecosystem goods and services benefits of the retention basin at Pelly's Lake, MB (\$/hectare of retention basin) \\
Carbon credits & 4800.00 \\
Phosphorus removed & $12,720.00$ \\
Nitrogen removed & $0.55-741.30$ \\
Avoided flooding costs (estimate from adjacent watershed in MB; estimate from literature) & $17,730.00-18,470.00$ \\
Total &
\end{tabular}

production capacity and nutrient retention are considered. Using the retention basin for cattail production and harvest directly benefits the farmer and also provides additional benefits to the province of Manitoba through carbon sequestration and nutrient removal from surface water. Harvesting cattails for biomass from the retention basin at Pelly's Lake, MB, can provide an actual realized value of $\$ 642.70 /$ hectare of harvestable cattail/year (Table 3). This value considered the current revenue gains available for cattail biomass and carbon offset credits. Monetizing the ecosystem goods and services of carbon offset credits using a global social carbon credit value increases the value of biomass production at Pelly's Lake. The higher carbon credit value combined with the monetized value of phosphorus and nitrogen removed from the ecosystem during cattail harvest from the retention basin at Pelly's Lake, $\mathrm{MB}$, provides a monetized benefit of $\$ 8014 /$ hectare of harvestable cattail/year (Table 3).

The retention basin itself provides nutrient removal, carbon sequestration, and avoided flooding costs. The valuation of avoided flooding costs, based on the average global wetland flood control value, was much higher than avoided flooding infrastructure damage cost estimates from a report in the rural municipality of Stanley, MB (Stanley Soil Management Association 2000; Schuyt and Brander 2004; Brander et al. 2013). Thus, a range in estimates was provided for avoided flooding costs. Monetizing these ecosystem goods and services benefits of retention basins, there is potential to gain $\$ 17,730.00-\$ 18,470.00 /$ hectare of retention basin/year from its installation at Pelly's Lake (Table 3).

\section{Sensitivity analysis}

Reservoir and irrigation cost adjustments (5\% increase and decrease, $10 \%$ increase and decrease) resulted in similar increases and decreases to net revenue. A net revenue of -\$160.00/hectare became $-\$ 176.00 /$ hectare when reservoir and irrigation costs were increased by $10 \%$. Slight variation to net revenue percent increases and decreases was experienced (average variation of $1 \%$ ) due to operating costs, also being subtracted from gross revenue, remaining constant. Sensitivity analyses of crop price did have an effect on yearly revenue. As crop price increased, the impact on gross crop revenue increased (Table 4). The nonlinearity of the impact of crop price variation is due to the variability in the precipitation time series and the nonlinear water sufficiency curves. The irrigation algorithm used for irrigation application also resulted in a slightly higher standard deviation when crops were irrigated versus non-irrigated crops. As crop yield fell to $80 \%$ of actual yield, irrigation was triggered. In some instances, this would have been caused by an excess of water, rather than a lack of available water. In these cases, irrigation application would reduce yield.

The sensitivity analysis on initial reservoir water volume had very limited impact on gross revenue. All scenarios provided gross revenue changes below $0.1 \%$. Variance to maximum daily irrigation water volume had a small effect in most scenario years, except in 2013 (Table 5). The impact in 2013 was more substantial, with higher volumes of water providing up to $38 \%$ greater revenue. The year 2013 experienced the second lowest precipitation during 
Table 4 Sensitivity analysis illustrating average net revenue change (\%) when crop prices on non-irrigated and irrigated crops were adjusted

\begin{tabular}{|c|c|c|c|c|}
\hline Scenario & $\begin{array}{l}\text { Net revenue } \\
\text { average change on } \\
\text { irrigated crops }(\%)\end{array}$ & $\begin{array}{l}\text { Standard deviation of net revenue } \\
\text { average change on irrigated crops }\end{array}$ & $\begin{array}{l}\text { Net revenue } \\
\text { average change on non- } \\
\text { irrigated crops }(\%)\end{array}$ & $\begin{array}{l}\text { Standard deviation of net revenue } \\
\text { average change on non-irrigated crops }\end{array}$ \\
\hline $\begin{array}{l}10 \% \text { Crop } \\
\text { price } \\
\text { increase }\end{array}$ & +11.8 & 4.51 & +11.7 & 4.19 \\
\hline $\begin{array}{l}10 \% \text { Crop } \\
\text { price } \\
\text { decrease }\end{array}$ & -8.56 & 3.69 & -8.66 & 3.42 \\
\hline $\begin{array}{l}25 \% \text { Crop } \\
\text { price } \\
\text { increase }\end{array}$ & +27.1 & 5.13 & +26.9 & 4.76 \\
\hline $\begin{array}{l}25 \% \text { Crop } \\
\text { price } \\
\text { decrease }\end{array}$ & -23.8 & 3.07 & -23.9 & 2.85 \\
\hline $\begin{array}{l}50 \% \text { Crop } \\
\text { price } \\
\text { increase }\end{array}$ & +52.3 & 6.16 & +52.1 & 5.72 \\
\hline $\begin{array}{l}50 \% \text { Crop } \\
\text { price } \\
\text { decrease }\end{array}$ & -49.2 & 2.05 & -49.3 & 1.90 \\
\hline
\end{tabular}

Base crop prices: (1) Alfalfa—\$132.28/tonne, (2) Barley— $\$ 173.23 /$ tonne, (3) Canola— $\$ 418.87 /$ tonne, and (4) Spring wheat— $\$ 238.83 /$ tonne

Table 5 Sensitivity analysis illustrating average net revenue change when maximum daily irrigation water volumes on irrigated crops were varied (base maximum daily irrigation water volume is $\left.15,000 \mathrm{~m}^{3}\right)$

\begin{tabular}{lll}
\hline $\begin{array}{l}\text { Maximum daily irrigation } \\
\text { water volume withdrawal }\end{array}$ & $\begin{array}{l}\text { Net revenue } \\
\text { average change }(\%)\end{array}$ & $\begin{array}{l}\text { Net revenue } \\
\text { standard deviation }\end{array}$ \\
\hline $75,000 \mathrm{~m}^{3}$ & +4.64 & 10.9 \\
$65,000 \mathrm{~m}^{3}$ & +4.64 & 10.9 \\
$55,000 \mathrm{~m}^{3}$ & +4.56 & 10.8 \\
$45,000 \mathrm{~m}^{3}$ & +4.49 & 10.8 \\
$35,000 \mathrm{~m}^{3}$ & +3.86 & 9.08 \\
$25,000 \mathrm{~m}^{3}$ & +3.03 & 6.60 \\
$5000 \mathrm{~m}^{3}$ & +0.592 & 3.13 \\
\hline
\end{tabular}

the growing season $(200 \mathrm{~mm})$. There was also no initial water available in the reservoir. The variability in precipitation in 2013 provided conditions requiring significantly more irrigation than the other eleven simulated years.

The last sensitivity analysis was performed on the gap between actual and optimum yield. Net crop revenue fluctuated, on average, less than 2\% (4.3 standard deviation) in all four scenarios. This indicates that within the model, crop yield was not sensitive to the timing of irrigation application when soil water levels were at levels that could provide $60 \%$ or higher of optimal yield as they were already receiving adequate water for optimal growth.

\section{Discussion}

The economic benefits of adopting local farm surface water retention basins as a strategic water management strategy were investigated using a dynamic modeling system to address the study objectives. The first objective was to determine retention ponds capacity when used for irrigation purposes to provide a net economic advantage for farmers currently without a local farm retention system or irrigation infrastructure. Retention ponds used for irrigation on the study watersheds four main crops from 2002 to 2015 provided an average annual increase in gross crop revenue of $\$ 12.80 /$ hectare. However, due to the high cost associated with the installation and maintenance of the retention pond and irrigation equipment, the net cost to the participating farmer was an average of \$147.00/hectare each year. Replacing the existing low-value crops within the study area with high-value potato crops also resulted in a negative net revenue. Objective one results indicated that under current climate conditions, installation of retention basins for irrigation purposes remained not an economically viable investment for the farmer.

In the analysis, it was assumed that the farmer would be responsible for all costs associated with reservoir and irrigation infrastructure and maintenance. However, there is currently funding available within Manitoba to subsidize the cost of installing reservoirs due to their multiple 
downstream or societal benefits including wildlife habitat, carbon sequestration, phosphorus removal, and flood mitigation. The Growing Assurance Ecological Goods and Services Program, part of the Federal-Provincial initiative Growing Forward 2, is providing funding from 2013 to 2018 (Government of Manitoba 2015b). There is also funding available through nonprofit organizations such as the Manitoba Conservation District Association. For the Pelly's Lake reservoir, a total of $\$ 107,000$ in project management costs were covered by the LSRCD and its partners (La Salle Redboine Conservation District (LSRCD) 2015b). Applied to the overall cost of the reservoir, the in-kind contributions from LSRCD reduce the yearly reservoir costs to farmers at Pelly's Lake by $\$ 1.62 /$ ha/year. However, irrigation installation is not currently being subsidized in Manitoba. The average annual increase to crop revenue of $\$ 12.80 /$ hectare does not merit irrigation infrastructure installation at an annual cost of $\$ 152.00 /$ irrigated hectare. As average insurance costs for the four crops analyzed within the study site were $\$ 42.57 /$ hectare as of 2015, it makes more sense for the farmer to invest in insurance rather than irrigation (Government of Manitoba 2015a).

It is also important to note that the results from this study appear to be localized and represent the specific crop growth and irrigation characteristics of the target watershed. At the provincial level, 2002 and 2003 reported the third and second highest agricultural claims for drought (\$19.5 and \$25 million dollars, respectively) while 2006 experienced the highest level of drought insurance claims in the province (\$27 million dollars) (Manitoba Agricultural Services Corporation 2015). However, within the Victoria and Lorne census areas, that were the target of the present research, 2002 and 2003 received far more precipitation than in 2006 and had much lower insurance claims for drought (Manitoba Agricultural Services Corporation 2015). Drought insurance claims within the Victoria and Lorne census areas were instead higher in 2012 and 2013, which provincially saw low insurance claims (\$18 and \$22.5 million lower than 2006 claims, respectively) (Manitoba Agricultural Services Corporation 2015). In 2010, Manitoba saw $\$ 169$ million in claims for flooding (the second highest between 2002 and 2014) while the Victoria and Lorne census areas did not see any claims for flooding that year (Manitoba Agricultural Services Corporation 2015).

The second objective explored the economic benefits of retention basins capacity for biomass production, nutrient retention, and avoided flood damages. Using retention basins for these secondary benefits is not only economically beneficial to the farmer and government, but also to the environment. Harvesting cattails from the retention site for biomass and associated carbon offset credits, actual realized values, covers the yearly amortized cost of the reservoir and irrigation. It can also provide an increase in net revenue of $\$ 482.70 /$ hectare of retention basin/year. In the case of Pelly's Lake, one landowner owns the land on which the retention system is located. They would be benefitting from the additional revenue from cattail harvest, while downstream landowners would be directly benefitting from avoided flood damages. Monetizing the additional ecosystem goods and services benefits of cattail harvest provides $\$ 8014.00 /$ hectare of retention basin/year. The province of Manitoba would be realizing these benefits, as the province has yet to develop a market providing farmers with nitrogen and phosphorus capture credits. However, the actual realized value of cattail harvest allows the farmer to invest in retention basin and irrigation infrastructure enabling crop production stabilization and risk reduction in the face of predicted changes to precipitation and temperature in the future (Hassanzadeh et al. 2014; Pittman et al. 2011).

The removal of phosphorus, nitrogen, carbon, and avoided flooding damages of the retention basin itself provided an estimated additional $\$ 17,730 /$ hectare of retention basin/ year using a conservative valuation of avoided flooding damages. A conservative estimate was also used for wetland phosphorus absorption of $80 \mathrm{~kg} /$ hectare of wetland/year. Olewiler (2004) estimated wetlands can remove anywhere from 80 to $770 \mathrm{~kg} / \mathrm{hectare}$ of wetland/year of phosphorus. Using a value of $\$ 60.00 / \mathrm{kg}$ for phosphorus removed, a higher wetland phosphorus absorption rate would greatly increase the value of the multi-purpose retention system at Pelly's Lake, MB. There was also substantial variance in wetland nitrogen removal amounts and values. Nitrogen removal amounts ranged from 350 to $32,000 \mathrm{~kg} /$ hectare of wetland/ year, while removal rates ranged from $\$ 7.45$ to $\$ 140.10 / \mathrm{kg}$ (Collins and Gillies 2014; Olewiler 2004; Wilson 2008). For this research, the low-end nitrogen removal rate and a moderate value estimate of $\$ 36.34 / \mathrm{kg}$ for nitrogen removal from a constructed wetland was used. As with phosphorus, increasing these estimated rates would increase the value of the retention system at Pelly's Lake, MB.

Using multi-purpose retention basins for avoided flood damages, nutrient retention, and biomass production is not only economically beneficial to the farmer and government, but also to the environment. The province of Manitoba is committed to reducing downstream nutrient loading and has expressed interest in retention basins as a nutrient abatement option (Bourne et al. 2002; Government of Manitoba 2014; Grosshans et al. 2014; Lake Winnipeg Stewardship Board 2006). Manitoba's Surface Water Management Strategy (Government of Manitoba 2014) states that water storage and associated release strategies should optimize production and harvest of biomass resources to remove phosphorus from the aquatic environment. Removing these nutrients from the landscape via harvest reduces downstream nutrient loading. Additionally, the removal of phosphorus during cattail 
harvest increases the wetlands ability to store more phosphorus, benefiting downstream loading. This is essential for combating algal blooms and increasing water quality in aquatic environments such as Lake Winnipeg, Manitoba (Grosshans et al. 2014).

As the South Tobacco Creek Watershed has illustrated, a series of retention systems on the Manitoba landscape has the potential to reduce downstream loading of phosphorus and nitrogen. Over a 9-year period from 1999 to 2007, the retention system network decreased downstream nutrient loading above the Manitoba government's targets of 10 and $13 \%$ for phosphorus and nitrogen, respectively (Tiessen et al. 2011). As the average phosphorus and nitrogen concentrations in the watershed were still in excess of recommended levels in the Canadian Prairies, Tiessen et al. (2011) suggested using the reservoirs for local benefits, such as irrigation, would reduce downstream nutrient loading further. With the addition of cattail harvest, downstream loading of phosphorus and nitrogen would be further reduced.

As part of the retention system network in the South Tobacco Creek Watershed, Manitoba, a multi-purpose dam reduced peak flow caused by spring snowmelt by an average of $72 \%$ per year, with a range of $38-100 \%$ peak flow reduction/year. Summer rainfall generated peak flow was reduced an average of $48 \%$ per year by the same multi-purpose dam. The multi-purpose retention system at Pelly's Lake has only been operational for 2 years. However, in 2016, Pelly's Lake was already required to retain runoff from intense storm events in southwestern Manitoba. The reservoir at Pelly's Lake was full all summer and into the fall. There is discussion about constructing a second upstream reservoir which would increase storage capacity by $1,600,000 \mathrm{~m}^{3}$. This would greatly improve the retention systems ability to retain the majority or full volume of spring melt runoff.

Not all benefits of retention basins were included in this analysis. Reductions to downstream flooding also reduce damage to livestock, machinery, infrastructure, and crop lands. Retention basins also provide wildlife habitat and recreational services. At Pelly's Lake, the retention site is being used in a public education capacity. These benefits were not monetized in the current study as it is very difficult to determine an accurate value. However, inclusion of these benefits in the economic assessment would further increase the value of multi-purpose retention systems on the Manitoba landscape.

The retention basin installation at Pelly's Lake, with a total cost of $\$ 551,288$, could be paid off soon after installation when all the benefits of the retention pond are considered. Investing in multiple on-farm multi-purpose retention systems also has the potential to provide environmental and social benefits to the province of Manitoba. The reductions in phosphorus and nitrogen multi-purpose retention systems provide can aid in Manitoba's goal of reducing nitrogen and phosphorus concentrations by $50 \%$ to Lake Winnipeg (Government of Manitoba 2014). Rural municipalities and landowners benefit from the savings associated with avoided flooding damages, while the province of Manitoba and its population benefit from the reduction to downstream nutrient loading and carbon storage providing climate regulation.

\section{Conclusion}

The twelve-year present-day time period of this study highlighted the extreme variation in water availability to which Manitoba farmers are required to adapt. As witnessed in 2005 and 2006, precipitation amounts ranged from one extreme to the next (491 mm, 2005-127 mm, 2006) requiring farmers to be prepared for flood and drought conditions each year. The nutrient retention, flood damage reductions, carbon sequestration, and biomass production capacity of retention basins may provide the necessary economic and environmental benefits for their widespread adoption. Farmers, even without government subsidies, can afford retention basin installation to support irrigation practices if they choose to harvest cattails for biomass. Due to the economic and environmental gains retention basins provide to the province, subsidies could also be provided to incentivize widespread adoption. The recommended use of retention systems is for biomass production, nutrient retention, and avoided flood damages to support farmers wanting to invest in irrigation. This use will subsequently provide economic and environmental benefits for the government of Manitoba.

\section{Future directions}

Future research should explore potential environmental problems widespread retention system adoption could create. For example, an increase in stagnant water bodies would increase mosquito populations and impact expenditures on mosquito control. Additionally, high nutrient content in retention systems could cause environmental problems such as affecting dissolved oxygen levels. Finally, the economics of retention systems should be analyzed under future climate scenarios to determine their long-term economic feasibility on the Prairies.

Acknowledgements This work was supported by Environment and Climate Change Canada's Lake Winnipeg Basin Stewardship Fund and Growing Forward 2, which is gratefully acknowledged.

Open Access This article is distributed under the terms of the Creative Commons Attribution 4.0 International License (http:// creativecommons.org/licenses/by/4.0/), which permits unrestricted use, distribution, and reproduction in any medium, provided you give appropriate credit to the original author(s) and the source, provide a link to the Creative Commons license, and indicate if changes were made. 


\section{References}

Agriculture and Agri-Food Canada (2012) Positive effects of small dams and reservoirs: Water quality and quantity findings from a Prairie watershed. WEBS Fact Sheet \#7 4

APSIM Initiative (2016) APSIM Model. In: APSIM. https://www. apsim.info/AboutUs/APSIMModel.aspx. Accessed 4 June 2016

Armstrong RN, Pomeroy JW, Martz LW (2010) Estimating evaporation in a prairie landscape under drought conditions. Can Water Resour J 35:173-186. doi:10.4296/cwrj3502173

Arnold JG, Stockle CO (1991) Simulation of supplemental irrigation from on-farm ponds. J Irrigation Drain Eng 117:408-424

Avilés A, Niell FX (2007) The control of a small dam in nutrient inputs to a hypertrophic estuary in a Mediterranean climate. Water Air Soil Pollut 180:97-108. doi:10.1007/s11270-006-9253-4

Badiou P, McDougal R, Pennock D, Clark B (2011) Greenhouse gas emissions and carbon sequestration potential in restored wetlands of the Canadian prairie pothole region. Wetl Ecol Manag 19:237-256. doi:10.1007/s11273-011-9214-6

Belcher K (1999) Agroecosystem sustainability: an integrated modeling approach. University of Saskatchewan, Saskatoon

Belcher KW, Boehm MM, Zentner RP (2003) The economic value of soil quality under alternative management in the Canadian prairies. Can J Agric Econ 51:175-196. doi:10.1111/j.17447976.2003.tb00172.x

Belcher KW, Boehm MM, Fulton ME (2004) Agroecosystem sustainability: a system simulation model approach. Agric Syst 79:225-241. doi:10.1016/S0308-521X(03)00072-6

Bonsal BR, Wheaton EE, Chipanshi AC et al (2011) Drought research in Canada: a review. Atmos Ocean 49:303-319. doi:10.1080/ 07055900.2011 .555103

Bourne A, Armstrong N, Jones G (2002) A preliminary estimate of total nitrogen and total phosphorus loading to streams in Manitoba, Canada

Bower SS (2007) Watersheds: conceptualizing Manitoba's drained landscape, 1985-1950. Environ Hist Durh N C 12:796-819

Bower SS (2010) Natural and unnatural complexities: flood control along Manitoba's Assiniboine River. J Hist Geogr 36:57-67. doi:10.1016/j.jhg.2009.04.017

Brander L, Brouwer R, Wagtendonk A (2013) Economic valuation of regulating services provided by wetlands in agricultural landscapes: a meta-analysis. Ecol Eng 56:89-96. doi:10.1016/j. ecoleng.2012.12.104

Chen Z, Wei S (2014) Application of system dynamics to water security research. Water Resour Manag 28:287-300. doi:10. 1007/s11269-013-0496-8

Chrétien F, Gagnon P, Thériault G, Guillou M (2016) Performance analysis of a wet-retention pond in asmall agricultural catchment. J Environ Eng 142:4016005. doi:10.1017/ CBO9781107415324.004

Clarkson R, Deyes K (2002) Estimating the social cost of carbon emissions. London

Collins AR, Gillies N (2014) Constructed wetland treatment of nitrates: removal effectiveness and cost efficiency. J Am Water Resour Assoc 50:898-908. doi:10.1111/jawr.12145

Costanza R, Wainger L, Folke C, Maler K-G (1993) Modeling complex ecological economic systems: toward an evolutionary, dynamic understanding of human and nature. Bioscience 43:545-555. doi:10.2307/1311949

Costanza R, Duplisea D, Kautsky U (1998) Ecological modelling on modelling ecological and economic systems with STELLA. Ecol Modell 110:1-4

Costanza R, Voinov A, Boumans R et al (2002) Integrated ecological economic modeling of the Patuxent River watershed, Maryland. Ecol Monogr 72:203-231
Côté J, Desmarais J-G, Gravel S et al (1998) The operational CMCMRB global environmental multiscale (GEM) model. Part II. Results. Mon Weather Rev 126:1397-1418. doi:10.1175/15200493(1998)126<1397:TOCMGE > 2.0.CO;2

DDSAT Foundation (2016) DDSAT overview. In: DDSAT. http:// dssat.net/about. Accessed 4 June 2016

Dion J, McCandless M (2013) Cost-benefit analysis of three proposed distributed water storage options for manitoba. International Institute for Sustainable Development, Winnipeg

Gaia Consulting Limited (2007) 2006 Manitoba Irrigation Survey. Manitoba Agric Food Rural Initiat 1-20

Gohar AA, Ward FA, Amer SA (2013) Economic performance of water storage capacity expansion for food security. J Hydrol 484:16-25. doi:10.1016/j.jhydrol.2013.01.005

Government of Canada (2011) Census of Agriculture. In: CANSIM 2011. http://www.statcan.gc.ca/eng/ca2011/index. Accessed 1 Aug 2014

Government of Canada (2015) Daily data report. In: Hist. Clim. Data. http://climate.weather.gc.ca/. Accessed 1 Aug 2015

Government of Manitoba (2014) Surface Water Management Strategy

Government of Manitoba (2015a) Guidelines for Estimating Crop Production Costs 2015. Winnipeg, Manitoba

Government of Manitoba (2015b) About Growing Forward 2. In: Manitoba Agric. Food Rural Dev. http://www.gov.mb.ca/ agriculture/growing-forward-2/about.html. Accessed 30 Nov 2015

Government of Manitoba (2016) The Manitoba Advantage. In: Commod. Spec. Crop. http://www.gov.mb.ca/trade/globaltrade/ agrifood/commodity/potatoes.html. Accessed 1 June 2016

Grinder B (2000) Alberta's irrigation infrastructure. Lethbridge, Alberta

Grosshans R (2013) Technical and economic viability of cattail (typha spp.) biomass: a novel renewable and sustainable feedstock in the Manitoba bioeconomy. Winnipeg, Manitoba

Grosshans RE, P Gass, Dohan R et al (2012) Cattail harvesting for carbon offsets and nutrient capture: a "lake friendly" greenhouse gas project. International Institute for Sustainable Development, Manitoba

Grosshans R, Grieger L, Ackerman J et al (2014) Cattail biomass in a watershed-based bioeconomy: commercial-scale harvesting and processing for nutrient capture, biocarbon and high-value bioproducts. International Institute for Sustainable Development, Winnipeg

Hassanzadeh E, Elshorbagy A, Wheater H, Gober P (2014) Managing water in complex systems: an integrated water resources model for Saskatchewan, Canada. Environ Model Softw 58:12-26. doi:10.1016/j.envsoft.2014.03.015

Hearne RR (2007) Evolving water management institutions in the Red River Basin. Environ Manag 40:842-852. doi:10.1007/ s00267-007-9026-x

IPCC (2007) Summary for policymakers. In: Solomon S, Manning M, Chen $\mathrm{Z}$ et al. (eds), Climate Change 2007: the physical science basis. Contribution of Working Group 1 to the Fourth Assessment Report of the Intergovernmental Panel on Climate Change. Cambridge University Press, Cambridge, United Kingdom and New York

ISEE (2016) Model building and simulation tutorials. In: STELLA Softw. http://www.iseesystems.com/community/downloads/ tutorials/ModelBuilding.aspx. Accessed 9 Mar 2016

Keating BA, Carberry PS, Hammer GL et al (2003) An overview of APSIM, a model designed for farming systems simulation. Eur J Agron 18:267-288

Kovacic DA, Twait RM, Wallace MP, Bowling JM (2006) Use of created wetlands to improve water quality in the Midwest-Lake Bloomington case study. Ecol Eng 28:258-270. doi:10.1016/j. ecoleng.2006.08.002 
Kouwen N, Soulis ED, ASCE M et al (1993) Grouped response units for distributed hydrologic modeling. J Water Resour Plan Manag 119:289-305. doi:10.1061/(ASCE)0733-9496(1993)119:3(289)

La Salle Redboine Conservation District (LSRCD) (2007) La Salle River Watershed: State of the Watershed Report

La Salle Redboine Conservation District (LSRCD) (2013) Pelly's Lake Watershed Management Area. 1-2

La Salle Redboine Conservation District (LSRCD) (2015a) La Salle Redboine Conservation District: About. http://www. lasalleredboine.com/about. Accessed 24 Nov 2015

La Salle Redboine Conservation District (LSRCD) (2015b) La Salle Redboine Conservation District. http://www.lasalleredboine. $\mathrm{com} /$

Lake Winnipeg Stewardship Board (2006) Reducing nutrient loading to Lake Winnipeg and its watershed: our collective responsibility and commitment to action

Langman M (1986) Soils of the rural municipality of Lorne. Winnipeg, Manitoba

Langman MN (1989) Soils of the R.M. of Victoria. Winnipeg, Manitoba

Low B, Costanza R, Ostrom E et al (1999) Human-ecosystem interactions: a dynamic integrated model. Ecol Econ 31:227-242. doi:10.1016/S0921-8009(99)00081-6

Mahfouf J-F, Brasnett B, Gagnon S (2007) A Canadian precipitation analysis (CaPA) project: description and preliminary results. Atmos Ocean 45:1-17. doi:10.3137/ao.v450101

Manitoba Agricultural Services Corporation (2015) MMPP AgriInsurance Cause of Loss Data Browser. In: Manitoba Manag. Plus Progr. http://www.mmpp.com/mmpp.nsf/mmpp_browser_ cause_of_loss.html. Accessed 3 Sept 2014

Manitoba Agricultural Services Corporation (2016) Current MASC Lending Rates. In: MASC Lend. http://www.masc.mb.ca/masc. nsf/lending_rates.html. Accessed 4 March 2016

Manitoba Liquor and Lotteries Corporation (2016) Environmental Innovation. In: Entertain. Good. http://www.mbll.ca/content/ environmental-innovation. Accessed 12 Dec 2016

Mengistu SG, Spence C (2016) Testing the ability of a semidistributed hydrological model to simulate contributing area. Water Resour Res 52:4399-4415. doi:10.1002/2016WR018760

Mirchi A, Madani K, Watkins D, Ahmad S (2012) Synthesis of system dynamics tools for holistic conceptualization of water resources problems. Water Resour Manag 26:2421-2442. doi:10. 1007/s11269-012-0024-2

Olewiler N (2004) The value of natural capital in settled areas of Canada

Ouyang Y, Zhang JE, Lin D, Liu GD (2010) A STELLA model for the estimation of atrazine runoff, leaching, adsorption, and degradation from an agricultural land. J Soils Sediments 10:263-271. doi:10.1007/s11368-009-0107-8

Pavelic P, Srisuk K, Saraphirom P et al (2012) Balancing-out floods and droughts: opportunities to utilize floodwater harvesting and groundwater storage for agricultural development in Thailand. J Hydrol 470-471:55-64. doi:10.1016/j. jhydrol.2012.08.007

Pietroniro A, Fortin V, Kouwen N et al (2007) Development of the MESH modelling system for hydrological ensemble forecasting of the Laurentian Great Lakes at the regional scale. Hydrol Earth Syst Sci 11:1279-1294. doi:10.5194/hessd-3-2473-2006

Pittman J, Wittrock V, Kulshreshtha S, Wheaton E (2011) Vulnerability to climate change in rural Saskatchewan: case study of the Rural Municipality of Rudy No. 284. J Rural Stud 27:83-94. doi:10.1016/j.jrurstud.2010.07.004

Pomeroy JW, de Boer D, Martz LW (2005) Hydrology and water resources of Saskatchewan. Centre for Hydrology, University of Saskatchewan, Saskatoon
Pomeroy J, Fang X, Williams B (2011) Modelling snow water conservation on the Canadian Prairies. Centre for Hydrology, University of Saskatchewan, Saskatoon

Qaiser K, Ahmad S, Johnson W, Batista JR (2013) Evaluating water conservation and reuse policies using a dynamic water balance model. Environ Manag 51:449-458. doi:10.1007/s00267-0129965-8

Rao NS, Easton ZM, Lee DR, Steenhuis TS (2012) Economic analysis of best management practices to reduce watershed phosphorus losses. J Environ Qual 41:855-864. doi:10.2134/ jeq2011.0165

Rittenburg RA, Squires AL, Boll J et al (2015) Agricultural BMP effectiveness and dominant hydrological flow paths: concepts and a review. J Am Water Resour Assoc 51:305-329. doi:10. $1111 / 1752-1688.12293$

Salvia-Castellvi M, Dohet A, Vander Borght P, Hoffmann L (2001) Control of the eutrophication of the reservoir of Esch-sur-Sûre (Luxembourg): evaluation of the phosphorus removal by predams. Hydrobiologia 459:61-71. doi:10.1023/A: 1012548006413

Samarawickrema A, Kulshreshtha S (2008) Value of irrigation water for drought proofing in the South Saskatchewan River Basin (Alberta). Can Water Resour J 33:273-282. doi:10.4296/ cwrj3303273

Schuyt K, Brander L (2004) The economic values of the world's wetlands. World Wildlife Fund, Netherlands

Sharpley A, Smith SJ, Zollweg JA, Coleman GA (1996) Gully treatment and water quality in the Southern Plains. J Soil Water Conserv 51:498-503

Simonovic SP, Li LH (2004) Sensitivity of the Red River basin flood protection system to climate variability and change. Water Resour Manag 18:89-110. doi:10.1023/B:WARM.0000024702. 40031.b2

Sohngen B, King KW, Howard G et al (2015) Nutrient prices and concentrations in Midwestern agricultural watersheds. Ecol Econ 112:141-149. doi:10.1016/j.ecolecon.2015.02.008

Stanley Soil Management Association (2000) Upper Hespler Watershed Assessment Project

Stephenfield Lake Watershed Round Table (2005) Stephenfield lake watershed management plan

Sterman JD (2000) Business dynamics: systems thinking and modeling for a complex world. The McGraw-Hill Companies Inc., New York

Tiessen KHD, Elliott JA, Stainton M et al (2011) The effectiveness of small-scale headwater storage dams and reservoirs on stream water quality and quantity in the Canadian Prairies. J Soil Water Conserv 66:158-171. doi:10.2489/jswc.66.3.158

University of Saskatchewan (2015) MEC-surface and hydrology (MESH). http://www.usask.ca/ip3/models1/mesh.htm. Accessed 15 Oct 2015

Uusi-Kämppä J, Braskerud B, Jansson H et al (2000) Buffer zones and constructed wetlands as filters for agricultural phosphorus. J Environ Qual 29:151-158. doi:10.2134/jeq2000. $00472425002900010019 x$

Venema HD, Oborne B, Neudoerffer C (2010) The Manitoba challenge: linking water and land management for climate adaptation. International Institute for Sustainable Development, Winnipeg

Verseghy DL (1991) CLASS - a Canadian land surface scheme for GCMS. I. Soil model. Int J Climatol 11:111-133. doi:10.1002/ joc. 3370110202

Verseghy DL, McFarlane NA, Lazare M (1993) CLASS—a Canadian land surface scheme for GCMS, II. Vegetation model and coupled runs. Int J Climatol 13:347-370. doi:10.1002/joc. 3370110202 
Viji R, Prasanna PR, Ilangovan R (2015) Gis Based SCS-CN method for estimating runoff In Kundahpalam watershed, Nilgries District, Tamilnadu. Earth Sci Res J 19:59-64. doi:10.15446/ esrj.v19n1.44714

Vorogushyn S, Lindenschmidt K-E, Kreibich H et al (2012) Analysis of a detention basin impact on dike failure probabilities and flood risk for a channel-dike-floodplain system along the river Elbe, Germany. J Hydrol 436-437:120-131. doi:10.1016/j.jhydrol. 2012.03.006
Waelti C, Spuhler D (2012) Retention basin. In: Sustain. Sanit. Water Manag. http://www.sswm.info/content/retention-basin. Accessed 14 Aug 2014

Wilson SJ (2008) Lake Simcoe basin's natural capital: the value of the watershed's ecosystem services. Vancouver 